\title{
The Analysis of the Relation Between Preschool Teachers' Decision Making and Attachment Styles
}

\author{
Duygu Yalman Polatlar ${ }^{1} \&$ Muhammet Ü. Öztabak ${ }^{2}$ \\ ${ }^{1}$ Faculty of Education, Department of Early Childhood Education, Fatih Sultan Mehmet Vakıf University, \\ Istanbul, Turkey \\ ${ }^{2}$ Faculty of Education, Department of Educational Sciences, Fatih Sultan Mehmet Vakıf University, Istanbul, \\ Turkey \\ Correspondence: Duygu Yalman Polatlar, Faculty of Education, Department of Early Childhood Education, Fatih \\ Sultan Mehmet Vakıf University, Istanbul, Turkey.
}

Received: April 5, 2021

Accepted: June 18, 2021

Online Published: August 22, 2021

doi:10.5539/ies.v14n9p1

URL: https://doi.org/10.5539/ies.v14n9p1

\begin{abstract}
The aim of this study is to analyze the relation between preschool teachers' decision making styles and attachment styles in the context of classroom management. Correlational Survey Method, which is one of the quantitative research methods, has been used in the study. The universe of the study comprises preschool teachers working in state and private schools in the European part of İstanbul. The sample of the study, which is 380 preschool teachers, has been selected through random selection. The data of the study have been collected through Teacher Information Form, Melbourne Decision Making Questionnaire I-II and Relationship Scale. Considering the relation between decision making styles and attachment styles as a result of the study, no significant relation has been found between vigilance decision making and attachment styles. There is weak and very weak relation between buck-passing, procrastination and hypervigilance decision making styles and fearful, preoccupied and dismissing attachment styles. A significant relation has been observed between decision making styles and income level and fathers' educational level. A significant relation has been noted between attachment styles and income level. There is no significant relation between other variables (sex, age, level of education) and the two styles.
\end{abstract}

Keywords: preschool teachers, attachment style, decision making style, classroom management

\section{Introduction}

The teacher is supposed to make decisions on many issues and keep the classroom under control. What kind of attitude the teacher will have in managing a classroom, however, is influenced by a lot of factors. People show a variety of reactions in situations where they need to make a decision. Decision making style is a learned pattern of reaction which an individual exhibits habitually (Scott \& Bruce, 1995). Each individual can use different styles when making a decision. For instance, some individuals have a rational and planned decision making style, whereas some have dependent, too meticulous, instinctive and deterinist styles (Balk1s, 2007).

Teaching context in the classroom is complicated and multi-dimensional. Dealing with complicated issues is a dominant factor in a teacher's life. The complicated life of teachers in the classroom can be better understood considering the relation between the decision making process of the teachers and the conditions and purposes she is trying to handle. Kounin (1970) states four aspects of decision making in a teaching context as follows:

1) Teachers make decisions when planning, applying and evaluating the teaching as well as creating appropriate conditions for a positive learning environment. Each step includes multi-dimensional classroom conditions and student features. When planning the teaching, for instance, teachers have to make a decision on aims, objectives, needs analysis, appropriate teaching strategies, materials, technology, and the evaluation of student performance. During the decision making process, many factors must be taken into account.

2) Teachers make decisions in each and every instance in order to adjust their plans to meet the ever-changing and unpredictable conditions in the classrooms. Teachers learn how to make such adjustments thanks to the information they have acquired in classrooms, interactive nature of their thoughts and their speculations about the subject.

3) Teachers make decisions so as to reach a variety of academic, social and behavioural objectives. For instance, a 
teacher can make decisions on observing student behaviour while working with a small group of students. At the same time, teachers can have expectations about the social and academic performances of the students. For his reason, teachers must take various objectives into account and make decisions on the styles of planning and applying objectives simultaneously.

4) Teachers make decisions to interact with the students in various styles in a complicated environment. For instance, teachers take some actions to observe students' off-task behaviours and respond to them. Their talent to be aware of what is going on in the classroom and to convey this awareness to the students through their actions is the reason why effective teachers are highly anxious.

In order to communicate effectively and openly with children, teachers need to shape the decision making process by focusing on what is best for children instead of what is best for themselves. The main point here is the fact that the teacher has information about himself and the children (Jones and Jones, 2004). In the interactive processes, such as determining the classroom rules and involving the children in the decision making process (Akdağ \& Haser, 2016) teachers' decision making styles have an important role. The decision making styles which have positive effects on the children-teacher interaction will strengthen in-class learning.

Decision is the point where individual's own values, society and personality intersect (Batçioğlu, 1994). The decision making styles that an individual has are closely related to personality features. And attachment has an important role in the formation of the personality. Bowlby (1973) defines attachment as strong emotional bonds that people develop towards other people who they consider important to themselves.

It is emphasized that just as they do in the relationships they establish with sensitive, responsive, and socially supportive parents, children can approach their teachers feeling emotionally safe and establish a relationship of such quality (Howes \& Hamilton, 1994). During preschool years, teachers can have a role as that of the parents of the children they are teaching and develop a pretty remarkable relationship with them (Hamilton \& Howes, 1992).

Developing Bowlby's work a little more, Bartholomew and Horowitz (1991) mentions foursome attachment. As a result of their studies, they put forth secure, fearful, preoccupied and dismissing attachment styles. Individuals with a secure attachment style evaluate themselves and others positively. It is observed that these individuals are extroverts who do not have problems with communicating or having relationships with others. The attachment style of individuals who evaluate themselves negatively while evaluating others positively is called preoccupied attachment. And individuals with an dismissing attachment style are the ones who evaluate themselves positively while evaluating others negatively. Finally, individuals who evaluate both themselves and others negatively are said to have a fearful attachment style. In the light of these studies, it can be argued that the attachment experienced during infancy has an effect on adults' relationship skills.

The attachment history of teachers plays an important role in their interactions with students. As to this, Pianta and Steinberg (1992) state that teachers' competence to perceive children's need for attachment and to show appropriate reactions can be explained to a great extent with the inner working models that they developed in their previous relationships. In their relations with students, teachers with a secure attachment style realise the importance of their roles and make an effort to be sensitive to their students' needs as well as empathising with them.

Related research indicates that securely attached teachers establish direct and more open communication with their students (Howes \& Ritchie, 2002; Simpson, Rholes, \& Phillips, 1996), and create a positive atmosphere in the classroom by using constructive conflict resolution strategies more (Morris-Rothschild, 2003), whereas insecurely attached teachers create a threatening environment in the classroom by establishing more defensive and oppressive communication (Howes \& Ritchie, 2002; Simpson \& Rholes, 1994).

In the context of preschool teachers' behaviours in the classroom, anxious teachers' worries about establishing and maintaining relationships with children and their families in the classroom are expected to bring a negative effect on both relationships. On the other hand, in similar relationships, buck-passing teachers are expected to be quite insufficient in areas such as relational support and empathising, whereas they are supposed to be a more responsible teacher figure, although they will be keeping an emotional distance in the classroom and towards families (Ata, 2014).

\subsection{Aim of the Research}

This research aims to analyze the relation between preschool teachers' decision making styles and attachment styles. With this aim in mind, the following questions will be answered:

1) What are preschool teachers' decision making styles and attachment styles? 
2) Is there a significant relation between preschool teachers' decision making styles and attachment styles?

3) Is there a difference between preschool teachers' decision making styles and attachment styles depending on their demographic features?

\section{Method}

\subsection{Model of the Research}

The model used in this research is correlational survey method, which is one of the qualitative research methods. Relational studies can be said to be effective in revealing the relations among variables and determining the levels of these relations as well as providing necessary clues for more advanced research about them (Büyüköztürk et al., 2016).

\subsection{Universe and Sample}

The universe of the research comprises preschool teachers working in state and private schools in the European part of İstanbul. The sample of the research is made up of teachers working in districts of Bakırköy, Eyüp, Fatih, Kâğıthane, Avcılar, and Bağcılar. The demographic features of the 380 preschool teachers chosen through random selection technique have been given in Table 1 .

Table 1. Frequency table of sample's demographic data

\begin{tabular}{|c|c|c|c|}
\hline & & $\mathrm{f}$ & $\%$ \\
\hline \multirow{3}{*}{ Sex } & Woman & 355 & 93.4 \\
\hline & Man & 25 & 6.6 \\
\hline & Total & 380 & 100 \\
\hline \multirow{5}{*}{ Age } & 25 years old and below & 101 & 26.6 \\
\hline & $26-30$ years old & 140 & 36.8 \\
\hline & 31-35 years old & 78 & 20.5 \\
\hline & 36 years and up & 61 & 16.1 \\
\hline & Total & 380 & 100 \\
\hline \multirow{3}{*}{ Education Level } & Associate & 146 & 38.4 \\
\hline & Undergraduate & 234 & 61.6 \\
\hline & Total & 380 & 100 \\
\hline \multirow{5}{*}{ Family's Economic Status } & Low & 2 & 0.5 \\
\hline & Medium & 133 & 35 \\
\hline & Good & 219 & 57.6 \\
\hline & High & 26 & 6.8 \\
\hline & Total & 380 & 100 \\
\hline \multirow{5}{*}{ Mother's Educational Level } & Primary & 145 & 38.2 \\
\hline & Secondary & 97 & 25.5 \\
\hline & High school & 110 & 28.9 \\
\hline & University & 28 & 7.4 \\
\hline & Total & 380 & 100 \\
\hline \multirow{5}{*}{ Father's Educational Level } & Primary & 102 & 26.8 \\
\hline & Secondary & 76 & 20.0 \\
\hline & High school & 140 & 36.8 \\
\hline & University & 62 & 16.3 \\
\hline & Total & 380 & 100 \\
\hline
\end{tabular}

As Table 1 shows, $93.4 \%$ of the teachers involved in the study are female while $6.6 \%$ are male. Of these teachers, $26.6 \%$ are 25 years old or younger, $36.8 \%$ are between 26 and $30,20.5 \%$ are between 31 and 35 , and $16.1 \%$ are 36 years old or above. The youngest teacher is 19 , while the oldest one is 57 . Of all the teachers, $38.4 \%$ are graduates of a two-year programme, while $61.6 \%$ are graduates of a four-year programme. The percentage of the teachers who perceive their income levels as average and good is 92.6 . Only $7.4 \%$ of the mothers and $16.3 \%$ of the fathers of the individuals involved in the study are university graduates. 


\subsection{Data Collection Tools}

The data of this research have been obtained through Teacher Information Form, Relationship Scale and Melbourne Decision Making Questionnaire I-II

\subsubsection{Teacher Information Form}

The information form, formed by the researchers include sex, age, education level, the perceived income level of the family, the education level of the parents.

\subsubsection{Melbourne Decision Making Questionnaire I-II}

Melbourne Decision Making Questionnaire, developed by Mann et al. (1998), was adapted to Turkey by Deniz (2004), who completed the validity and reliability studies. Melbourne Decision Making Questionnaire is divided into two parts. The first part comprises 6 items and aims to determine self-esteem (self-confidence) in decision making, and the second part comprises 22 items and aims to measure decision making styles. High points indicate that self-esteem in decision making is high. The questionnaire has 4 subfactors; Vigilance, Buck-passing, Procrastination, Hypervigilance.

In this research, as a result of the reliability analysis of Melbourne Decision Making Questionnaire's subdimensions, all of the cronbach alpha values have been found to be higher than 0,6 , with buck-passing decision making subdimension 0,701 , vigilance decision making subdimension 0.682 , procrastination decision making subdimension 0.673 and hypervigilance decision making subdimension 0.613 respectively. The cronbach alpha value of the Melbourne Decision Making Questionnaire is 0.73 , which indicates that the measurement tool used in this study is at a reliable level.

\subsubsection{Relationship Scale}

It is a 7-Likert type Questionnaire consisting of 30 items, each of which aims to measure the attachment style of adults. It was developed by Bartholomew and Horowitz (1991), and its validity and reliability studies were conducted by Sümer and Güngör (1999), who adapted it to Turkish. Its internal consistency coefficients range between .27 and .61 , while its test retest reliability coefficients range between .54 and .78 .

In this study, reliability analysis has been carried out and cronbach alpha coefficient has been calculated in order to measure the internal consistencies of relationship scale's subdimensions. The results show that the cronbach alpha value of all the subdimensions of the Relationship Scale is bigger than 0,6 , with fearful relationship subdimension being 0.823 , preoccupied relationship subdimension being 0.772 , secure relationship subdimension being 0.764 , and dismissing relationship subdimension being 0.694 respectively. The cronbach alpha value of the Relationship Scale is 0.83 , which indicates that the measurement tool used in this study is at a reliable level.

\subsection{Collection of Data}

The researchers listed the state and private schools found in the districts that they selected randomly. The directors of the schools on the list were contacted and the permission to apply the data collection tools were taken. Preschool teachers were asked if they wanted to participate in the research and the volunteers were given the measurement tools. The researchers went to the school again two days later to collect the forms which couldn't be filled in on the day of delivery.

\subsection{Analysis of Data}

The computer analysis of the obtained data was conducted using "SPSS for Windows 25.0". The descriptive frequency and percentage distribution of the teachers' demographic features were extracted. In accordance with the subgoals and variables of the research, $t$ test, one-way analysis of variance (ANOVA), post-hoc (LSD Multiple Comparison) test, and Pearson Product Moment Correlation analysis were carried out. Statistical analyses were tested as 2-tailed and the level of significance was accepted as .05.

\section{Findings and Results}

This part consists of the findings about the questions in the subgoals of the research.

\subsection{Findings About Preschool Teachers' Decision Making and Attachment Styles}

The data obtained about the question which is the first subgoal of the research, namely, "What are the decision making styles and attachment styles of preschool teachers?" have been presented in Table 2 and Table 3. 
Table 2. Descriptive statistics about the subdimensions of the decision making questionnaire

\begin{tabular}{lccccc}
\hline & $\mathrm{N}$ & Minimum & Maximum & Mean & Std. Deviation \\
\hline Self-esteem in Decision Making & 367 & 2.00 & 10.00 & 7.2670 & 1.38279 \\
Vigilance Decision Making & 361 & 2.00 & 12.00 & 9.6094 & 2.15118 \\
Buck-passing Decision Making & 365 & 0.00 & 12.00 & 3.5836 & 2.56386 \\
Procrastination Decision Making & 369 & 0.00 & 10.00 & 3.0081 & 2.27162 \\
Hypervgilance Decision Making & 367 & 0.00 & 10.00 & 3.5150 & 2.14353 \\
\hline
\end{tabular}

The average of teachers' points of self-esteem in decision making is 7.26, whereas standard deviation is 1.38. Teachers use vigilance (9.60) decision making style the most, followed by buck-passing (3.58), hypervigilance (3.51) and procrastination (3.00) decision making styles respectively.

Table 3. Descriptive statistics about the subdimensions of the relationship scale

\begin{tabular}{lccccc}
\hline & $\mathrm{N}$ & Minimum & Maximum & Mean & Std. Deviation \\
\hline Fearful & 380 & 5.00 & 35.00 & 14.8556 & 6.81012 \\
Secure & 380 & 8.00 & 54.00 & 31.8493 & 8.73408 \\
Preoccupied & 380 & 10.00 & 63.00 & 33.3428 & 10.02424 \\
Dismissing & 380 & 5.00 & 33.00 & 18.3611 & 6.18580 \\
\hline
\end{tabular}

Teachers use preoccupied (33.34) attachment style the most, followed by secure style (31.84), whereas the least used ones are fearful (14.85) and dismissing (18.36) attachment styles.

\subsection{Findings About the Relation Between Preschool Teachers' Decision Making Styles and Attachment Styles}

The data obtained as a result of the analysis made about the question which is the second subgoal of the research, namely, "Is there a significant relation between preschool teachers' decision making styles and attachment styles?" have been presented in Table 4.

Table 4. The correlation table between the subdimensions of the decision making questionnaire and relationship scale

\begin{tabular}{|c|c|c|c|c|c|}
\hline & & $\begin{array}{l}\vec{Z} \\
\mathbb{E} \\
\end{array}$ & 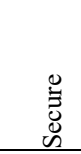 & 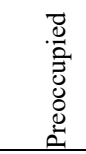 & $\begin{array}{l}.00 \\
.0 \\
.0 \\
.0 \\
.0\end{array}$ \\
\hline \multirow{3}{*}{ Vigilance Decision Making } & Pearson Correlation & -.075 & -.050 & -.040 & -.045 \\
\hline & Sig. (2-tailed) & .157 & .346 & .453 & .391 \\
\hline & $\mathrm{N}$ & 361 & 361 & 361 & 361 \\
\hline \multirow{3}{*}{ Buck-passing Decision Making } & Pearson Correlation & $.211^{* *}$ & .030 & $.215^{* *}$ & $.130^{*}$ \\
\hline & Sig. (2-tailed) & .000 & .573 & .000 & .013 \\
\hline & $\mathrm{N}$ & 365 & 365 & 365 & 365 \\
\hline \multirow{3}{*}{ Procrastination Decision Making } & Pearson Correlation & $.195^{* *}$ & .085 & $.162^{* *}$ & $.180^{* *}$ \\
\hline & Sig. (2-tailed) & .000 & .104 & .002 & .001 \\
\hline & $\mathrm{N}$ & 369 & 369 & 369 & 369 \\
\hline \multirow{3}{*}{ Hypervigilance Decision Making } & Pearson Correlation & $.216^{* *}$ & -.020 & $.350^{* *}$ & $.244^{* *}$ \\
\hline & Sig. (2-tailed) & .000 & .698 & .000 & .000 \\
\hline & $\mathrm{N}$ & 367 & 367 & 367 & 367 \\
\hline
\end{tabular}

* significant corelation at .05 level; ** significant corelation at .01 level.

The correlation coefficient between buck-passing decision making and fearful relationship is $0.211(\mathrm{p}<.05)$, and the correlation coefficient between the same decision making style and preoccupied relationship is $0.215(\mathrm{p}<.05)$. There is a weak positive relation between both variables. The correlation coefficient between buck-passing decision making and dismissing relationship is $0.130(\mathrm{p}<.05)$, and there is a very weak positive relation between the two variables. 
The correlation coefficient between procrastination decision making and fearful relationship is $0.195(\mathrm{p}<.05)$, and the correlation coefficients between the same decision making style and preoccupied relationship and dismissing relationship are $0.162(\mathrm{p}<.05)$ and $0.180(\mathrm{p}<.05)$ respectively. There is a very weak positive relation between both variables.

The correlation coefficient between hypervigilance decision making and fearful relationship is 0.216 ( $p<.05$ ), and the correlation coefficients between the same decision making style and preoccupied relationship and dismissing relationship are $0.350(\mathrm{p}<.05)$ and $0.244(\mathrm{p}<.05)$ respectively. There is a weak positive relation between both variables.

\subsection{Findings About Preschool Teachers' Decision Making Styles and Attachment Styles According to Various Demographic Features}

The results of the analysis made about the question which is the third subgoal of the research, namely, "Do preschool teachers' decision making styles and attachment styles differ according to their demographic features?" are stated below.

It has been observed that teachers' decision making styles have a significant relation with demographic variables such as family's economic situation and father's education level. Also, teachers' attachment styles have a significant relation with demographic variables such as family's economic status. There is no significant relation in the other variables (sex, age, education level). Only the analysis results of the variables found to have a significant difference have been presented in tables.

The results of the ANOVA, carried out in order to determine if preschool teachers' decision making styles differ according to income level variable, can be seen in Table 5.

Table 5. The ANOVA results of decision making styles according to income level

\begin{tabular}{|c|c|c|c|c|c|c|c|c|}
\hline & & \multirow[b]{2}{*}{$\mathrm{N}$} & \multirow[b]{2}{*}{ Mean } & \multirow[b]{2}{*}{ Std. Dev. } & \multicolumn{2}{|c|}{ 95\% Confidence Interval } & \multirow[b]{2}{*}{$\mathrm{F}$} & \multirow[b]{2}{*}{$\mathrm{p}$} \\
\hline & & & & & $\begin{array}{c}\text { Lower } \\
\text { Bond }\end{array}$ & Upper Bond & & \\
\hline \multirow{4}{*}{$\begin{array}{c}\text { Self-esteem in } \\
\text { Decision making }\end{array}$} & Middle & 130 & 7.1538 & 1.53745 & 6.8871 & 7.4206 & \multirow{4}{*}{1.474} & \multirow{4}{*}{0.230} \\
\hline & Good & 213 & 7.2911 & 1.27744 & 7.1185 & 7.4636 & & \\
\hline & High & 24 & 7.6667 & 1.37261 & 7.0871 & 8.2463 & & \\
\hline & Total & 367 & 7.2670 & 1.38279 & 7.1251 & 7.4090 & & \\
\hline \multirow{4}{*}{$\begin{array}{c}\text { Vigilance Decision } \\
\text { Making }\end{array}$} & Medium & 127 & 9.7402 & 2.25449 & 9.3443 & 10.1361 & \multirow{4}{*}{0.392} & \multirow{4}{*}{0.676} \\
\hline & Good & 209 & 9.5263 & 2.12144 & 9.2370 & 9.8156 & & \\
\hline & High & 25 & 9.6400 & 1.89033 & 8.8597 & 10.4203 & & \\
\hline & Total & 361 & 9.6094 & 2.15118 & 9.3868 & 9.8321 & & \\
\hline \multirow{4}{*}{$\begin{array}{c}\text { Buck-passing } \\
\text { Decision Making }\end{array}$} & Middle & 130 & 3.5769 & 2.55745 & 3.1331 & 4.0207 & \multirow{4}{*}{3.267} & \multirow{4}{*}{0.039} \\
\hline & Good & 213 & 3.4507 & 2.52603 & 3.1095 & 3.7919 & & \\
\hline & High & 22 & 4.9091 & 2.70641 & 3.7091 & 6.1090 & & \\
\hline & Total & 365 & 3.5836 & 2.56386 & 3.3197 & 3.8475 & & \\
\hline \multirow{4}{*}{$\begin{array}{l}\text { Procrastination } \\
\text { Decision Making }\end{array}$} & Middle & 130 & 3.0385 & 2.32080 & 2.6357 & 3.4412 & \multirow{4}{*}{1.348} & \multirow{4}{*}{0.261} \\
\hline & Good & 215 & 2.9116 & 2.23327 & 2.6114 & 3.2118 & & \\
\hline & High & 24 & 3.7083 & 2.31214 & 2.7320 & 4.6847 & & \\
\hline & Total & 369 & 3.0081 & 2.27162 & 2.7756 & 3.2407 & & \\
\hline \multirow{4}{*}{$\begin{array}{l}\text { Hypervigilance } \\
\text { Decision Making }\end{array}$} & Middle & 129 & 3.5349 & 2.04652 & 3.1784 & 3.8914 & \multirow{4}{*}{4.310} & \multirow{4}{*}{0.014} \\
\hline & Good & 215 & 3.3721 & 2.14676 & 3.0835 & 3.6607 & & \\
\hline & High & 23 & 4.7391 & 2.33972 & 3.7274 & 5.7509 & & \\
\hline & Total & 367 & 3.5150 & 2.14353 & 3.2950 & 3.7350 & & \\
\hline
\end{tabular}

Because the p-values of buck-passing and hypervigilance decision making styles are smaller than .05 significance level according to ANOVA results, there is a significant difference related to income level. As the p-values of other decision making styles are bigger than .05 significance level, no significant difference has been observed. In order to determine between which groups buck-passing and hypervigilance decision making styles make a difference, a post-hoc (multiple comparison) test has been carried out, and the results have been presented in Table 6 . 
Table 6. The results of multiple comparison according to income level

\begin{tabular}{|c|c|c|c|c|c|c|c|}
\hline \multicolumn{8}{|c|}{ LSD } \\
\hline \multirow{2}{*}{\multicolumn{3}{|c|}{ Dependent Variable }} & \multirow{2}{*}{ Mean Difference (I-J) } & \multirow{2}{*}{ Std. Error } & \multirow{2}{*}{$\mathrm{p}$} & \multicolumn{2}{|c|}{$95 \%$ Confidence Interval } \\
\hline & & & & & & Lower Bond & Upper Bond \\
\hline \multirow{6}{*}{ Buck-passing Decision Making } & \multirow{2}{*}{ Middle } & Good & .12622 & .28359 & .657 & -.4315 & .6839 \\
\hline & & High & $-1,33217^{*}$ & .58741 & .024 & -2.4873 & -.1770 \\
\hline & \multirow{2}{*}{ Good } & Middle & -.12622 & .28359 & .657 & -.6839 & .4315 \\
\hline & & High & $-1,45839^{*}$ & .57061 & .011 & -2.5805 & -.3363 \\
\hline & \multirow{2}{*}{ High } & Middle & $1,33217^{*}$ & .58741 & .024 & .1770 & 2.4873 \\
\hline & & Good & $1,45839^{*}$ & .57061 & .011 & .3363 & 2.5805 \\
\hline \multirow{6}{*}{ Hypervigilance Decision Making } & \multirow{2}{*}{ Middle } & Good & .16279 & .23659 & .492 & -.3025 & .6281 \\
\hline & & High & $-1,20425^{*}$ & .48084 & .013 & -2.1498 & -.2587 \\
\hline & \multirow{2}{*}{ Good } & Middle & -.16279 & .23659 & .492 & -.6281 & .3025 \\
\hline & & High & $-1,36704^{*}$ & .46606 & .004 & -2.2835 & -.4505 \\
\hline & \multirow{2}{*}{ High } & Middle & $1,20425^{*}$ & .48084 & .013 & .2587 & 2.1498 \\
\hline & & Good & $1,36704^{*}$ & .46606 & .004 & .4505 & 2.2835 \\
\hline
\end{tabular}

* The mean difference is significant at the 0.05 level.

After the multiple comparison test, no significant difference has been observed between the average and good income level groups in terms of buck-passing and hypervigilance decision making styles.

However, individuals from the high income group are significantly different from the average and good income groups in terms of buck-passing and hypervigilance decision making styles.

The results of the ANOVA test, carried out in order to determine if preschool teachers' decision making styles differ according to fathers' education level variable, have been presented in Table 7.

Table 7. The ANOVA results of decision making styles according to father's education level

\begin{tabular}{|c|c|c|c|c|c|c|c|c|}
\hline & & \multirow{2}{*}{$\mathrm{N}$} & \multirow{2}{*}{ Mean } & \multirow{2}{*}{ Std. Deviation } & \multicolumn{2}{|c|}{ 95\% Confidence Interval } & \multirow{2}{*}{$\mathrm{F}$} & \multirow{2}{*}{$\mathrm{p}$} \\
\hline & & & & & Lower Bond & Upper Bond & & \\
\hline \multirow{5}{*}{ Self-Esteem in Decision Making } & Primary School & 100 & 7.5200 & 1.14133 & 7.2935 & 7.7465 & \multirow{5}{*}{3.660} & \multirow{5}{*}{0.013} \\
\hline & Secondary School & 71 & 7.0423 & 1.68554 & 6.6433 & 7.4412 & & \\
\hline & High School & 135 & 7.0667 & 1.42053 & 6.8249 & 7.3085 & & \\
\hline & University & 61 & 7.5574 & 1.16225 & 7.2597 & 7.8550 & & \\
\hline & Total & 367 & 7.2670 & 1.38279 & 7.1251 & 7.4090 & & \\
\hline \multirow{5}{*}{ Vigilance Decision Making } & Primary School & 97 & 9.8041 & 2.13912 & 9.3730 & 10.2353 & \multirow{5}{*}{0.612} & \multirow{5}{*}{0.608} \\
\hline & Secondary School & 71 & 9.4507 & 2.32249 & 8.9010 & 10.0004 & & \\
\hline & High School & 136 & 9.4926 & 2.12915 & 9.1316 & 9.8537 & & \\
\hline & University & 57 & 9.7544 & 2.02026 & 9.2183 & 10.2904 & & \\
\hline & Total & 361 & 9.6094 & 2.15118 & 9.3868 & 9.8321 & & \\
\hline \multirow{5}{*}{ Buck-passing Decision Making } & Primary School & 100 & 3.2000 & 2.54257 & 2.6955 & 3.7045 & \multirow{5}{*}{1.666} & \multirow{5}{*}{0.174} \\
\hline & Secondary School & 72 & 4.0417 & 2.87993 & 3.3649 & 4.7184 & & \\
\hline & High School & 135 & 3.6889 & 2.53179 & 3.2579 & 4.1199 & & \\
\hline & University & 58 & 3.4310 & 2.18537 & 2.8564 & 4.0056 & & \\
\hline & Total & 365 & 3.5836 & 2.56386 & 3.3197 & 3.8475 & & \\
\hline \multirow{5}{*}{ Procrastination Decision Making } & Primary School & 100 & 2.8700 & 2.31226 & 2.4112 & 3.3288 & \multirow{5}{*}{0.557} & \multirow{5}{*}{0.644} \\
\hline & Secondary School & 75 & 3.1467 & 2.57164 & 2.5550 & 3.7383 & & \\
\hline & High School & 137 & 2.9197 & 2.18302 & 2.5509 & 3.2885 & & \\
\hline & University & 57 & 3.2807 & 1.99781 & 2.7506 & 3.8108 & & \\
\hline & Total & 369 & 3.0081 & 2.27162 & 2.7756 & 3.2407 & & \\
\hline \multirow{4}{*}{ Hypervigilance Decision Making } & Primary School & 99 & 3.1010 & 2.01269 & 2.6996 & 3.5024 & \multirow{4}{*}{2.185} & \multirow{4}{*}{0.089} \\
\hline & Secondary School & 70 & 3.9286 & 2.34256 & 3.3700 & 4.4871 & & \\
\hline & High School & 138 & 3.5942 & 2.18367 & 3.2266 & 3.9618 & & \\
\hline & University & 60 & 3.5333 & 1.94384 & 3.0312 & 4.0355 & & \\
\hline
\end{tabular}




$\begin{array}{llllll}\text { Total } & 367 & 3.5150 & 2.14353 & 3.2950 & 3.7350\end{array}$

Since the p-value related to the point of self-esteem in decision making is smaller than .05 significance level according to the ANOVA test, preschool teachers' points of self-esteem in decision making according to fathers' education level differ significantly. As the p-values of other decision making styles are bigger than .05 significance level, no significant difference has been observed. In order to determine the different group or groups, a post-hoc test has been conducted (Table 8 ).

Table 8 . The results of multiple comparison according to father's education level

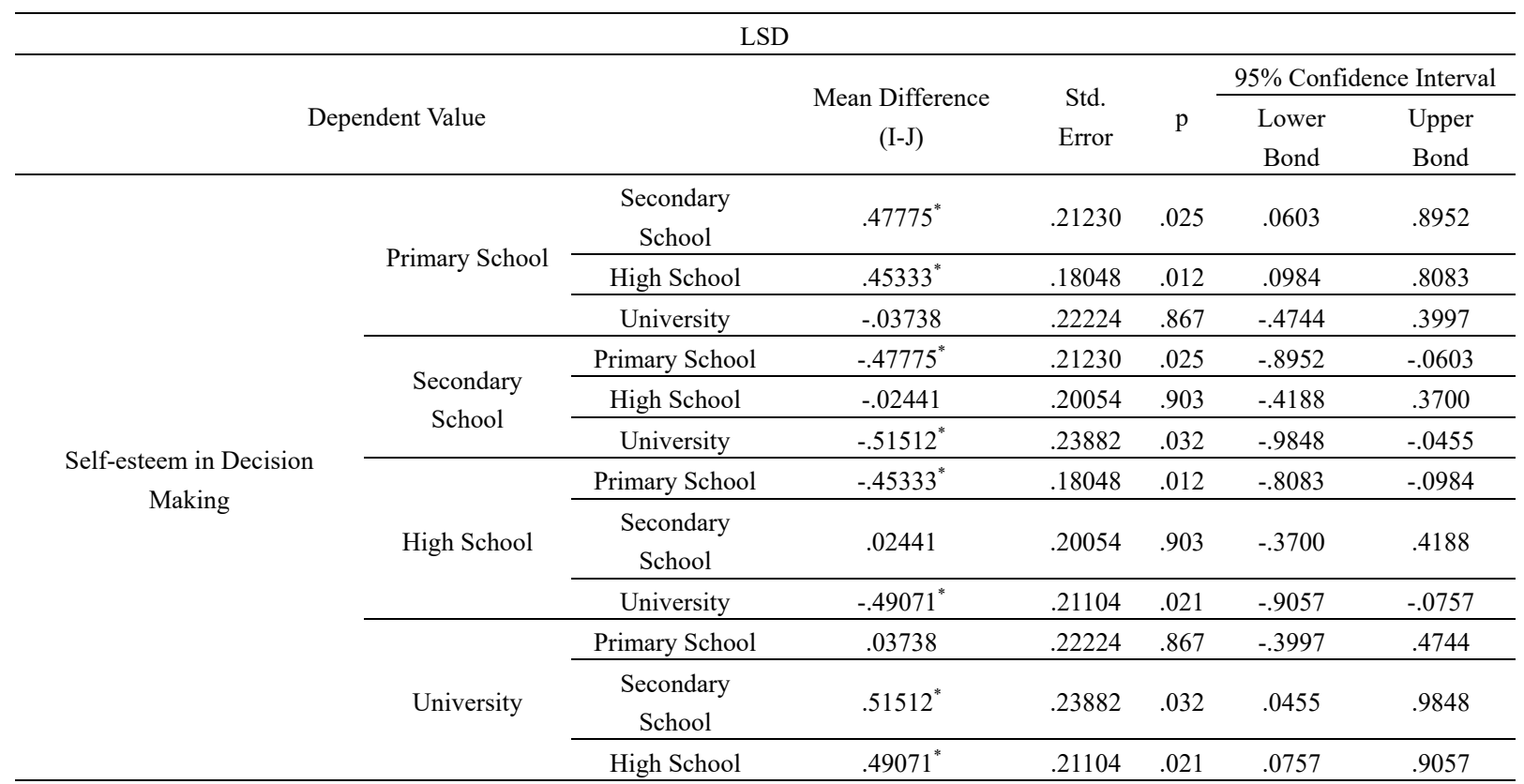

* The mean difference is significant at the 0.05 level.

As a result of the multiple comparison, it has been found that self-esteem in decision making points of preschool teachers whose fathers' education level is primary school or university are higher than the points of those whose fathers' education level is secondary school or high school. There is a significant difference neither between teachers whose fathers are primary school and university graduates, nor between the ones whose fathers are secondary school and high school graduates.

The results of the ANOVA test, carried out in order to determine if preschool teachers' attachment styles differ according to income level variable, have been presented in Table 9.

Table 9. The ANOVA results according to family income level

\begin{tabular}{|c|c|c|c|c|c|c|c|c|}
\hline & & \multirow{2}{*}{$\mathrm{N}$} & \multirow{2}{*}{ Mean } & \multirow{2}{*}{ Std. Dev. } & \multicolumn{2}{|c|}{$95 \%$ Confidence Interval } & \multirow{2}{*}{$\mathrm{F}$} & \multirow{2}{*}{$\mathrm{p}$} \\
\hline & & & & & Lower Bond & Upper Bond & & \\
\hline \multirow{4}{*}{ Fearful } & Middle & 135 & 14.1440 & 6.44762 & 13.0465 & 15.2416 & \multirow{4}{*}{2.626} & \multirow{4}{*}{0.074} \\
\hline & Good & 219 & 14.9915 & 6.94001 & 14.0672 & 15.9157 & & \\
\hline & High & 26 & 17.4062 & 7.11417 & 14.5327 & 20.2797 & & \\
\hline & Total & 380 & 14.8556 & 6.81012 & 14.1687 & 15.5425 & & \\
\hline \multirow{4}{*}{ Secure } & Middle & 135 & 33.3389 & 9.04498 & 31.7992 & 34.8785 & \multirow{4}{*}{7.034} & \multirow{4}{*}{0.001} \\
\hline & Good & 219 & 30.5004 & 8.10489 & 29.4210 & 31.5799 & & \\
\hline & High & 26 & 35.4765 & 10.17565 & 31.3665 & 39.5865 & & \\
\hline & Total & 380 & 31.8493 & 8.73408 & 30.9683 & 32.7303 & & \\
\hline \multirow{4}{*}{ Preoccupied } & Middle & 135 & 32.9570 & 9.75621 & 31.2962 & 34.6177 & \multirow{4}{*}{0.871} & \multirow{4}{*}{0.419} \\
\hline & Good & 219 & 33.2912 & 10.21166 & 31.9312 & 34.6512 & & \\
\hline & High & 26 & 35.7807 & 9.84180 & 31.8055 & 39.7559 & & \\
\hline & Total & 380 & 33.3428 & 10.02424 & 32.3317 & 34.3539 & & \\
\hline
\end{tabular}




\begin{tabular}{lcccccc}
\hline \multirow{4}{*}{ Dismissing } & Middle & 135 & 17.7357 & 6.28856 & 16.6652 & 18.8062 \\
\cline { 2 - 7 } & Good & 219 & 18.5746 & 6.10482 & 17.7615 & 19.3876 \\
\cline { 2 - 7 } & High & 26 & 19.8103 & 6.19977 & 17.3062 & 22.3145 \\
\cline { 2 - 7 } & Total & 380 & 18.3611 & 6.18580 & 17.7372 & 18.9851 \\
\hline
\end{tabular}

Preschool teachers' secure relationship levels differ significantly depending on their family income levels. A multiple comparison test has been conducted in order to understand which group or groups the difference stems from. The results have been presented in the table below. In the multiple comparison table, there are significant differences between the comparisons whose p-value is smaller than .05 .

Table 10. The results of the multiple comparison test according to family income level

\begin{tabular}{|c|c|c|c|c|c|c|c|}
\hline \multicolumn{8}{|c|}{ LSD } \\
\hline \multirow{2}{*}{\multicolumn{3}{|c|}{ Dependent Value }} & \multirow{2}{*}{ Mean Difference (I-J) } & \multirow{2}{*}{ Std. Hata } & \multirow{2}{*}{$\mathrm{p}$} & \multicolumn{2}{|c|}{ 95\% Confidence Interval } \\
\hline & & & & & & Lower Bond & Upper Bond \\
\hline \multirow{6}{*}{ Secure } & \multirow{2}{*}{ Middle } & Good & $2,83843^{*}$ & .94086 & .003 & .9884 & 4.6884 \\
\hline & & High & -2.13763 & 1.84149 & .246 & -5.7585 & 1.4833 \\
\hline & \multirow{2}{*}{ Good } & Middle & $-2,83843^{*}$ & .94086 & .003 & -4.6884 & -.9884 \\
\hline & & High & $-4,97606^{*}$ & 1.78355 & .006 & -8.4830 & -1.4691 \\
\hline & \multirow{2}{*}{ High } & Middle & 2.13763 & 1.84149 & .246 & -1.4833 & 5.7585 \\
\hline & & Good & $4,97606^{*}$ & 1.78355 & .006 & 1.4691 & 8.4830 \\
\hline
\end{tabular}

* The mean difference is significant at the 0.05 level.

As a result of the multiple comparison test, it has been found that there is a significant difference since the p-value between the average and good income group is $(0,003)<.05$. The secure relationship points of the individuals from the average income group is higher. At the same time, there is a significant difference between good and high income groups as the p-value between the individuals from these groups is $(0,006)<.05$. The point of the high income group is higher than the point of good income group. However, no significant difference has been observed between the individuals from the average income group and the ones from the high income group.

\section{Discussion}

Teachers involved in the research use vigilance decision making style the most. Then come buck-passing, hypervigilance and procrastination decision making styles respectively. It has also been found that self-esteem (self-confidence) points of the teachers are high. As to attachment styles, teachers use preoccupied style the most, with secure style coming after it. The least used ones are fearful and dismissing attachment styles.

It has been observed that preschool teachers use vigilance decision making style, which is about looking for information meticulously and making choices only after evaluating the alternatives vigilancely. According to Taşdelen's (2001) research, teacher candidates use rational decision making style the most. In their reseach about school directors, Izgar and Yilmaz (2007) found a positive relation between the level of self-esteem and vigilance decision making style, whereas they found a negative one between self-esteem and the other styles.

In various studies, it has been stated that the average points of teachers' self-esteem in decision making and their vigilance decision making styles are high, whereas the average points of their procrastination and hypervigilance styles are low (Çorapçı, 2015; Kırgil, 2015; Yılmaz \& Altınok, 2010).

Hariri, Monypenny, and Prideaux (2016) especially emphasize that teachers rational decision making styles contribute to their job satisfaction. In addition, the fact that there is a relation between teachers' job satisfaction and decision making styles is consistent with the results of other studies (Ejimofor, 2007; Hariri, 2011; Koutouzis \& Malliara, 2017).

That teachers use preoccupied attachment style more is related to the fact that they evaluate others positively while having negative ideas about their own selves. They need other people's opinions so as to feel valuable. They have a fear of not being accepted and of being rejected.

That teachers mostly use preoccupied attachment style can be explained with the fact that the mother figure in Turkish families is more protective, traditional and dependent. It is thought that because mothers are more in touch with their daughters and the father figure is more passive in child raising, children become more dependent on 
external factors.

Decision making styles have been found to have a significant relation with level of income and educational level of the father. A significant relation has also been found between attachment styles and level of income. There is no significant difference between other variables (sex, age, education level) and either style.

It has been observed that there is no significant difference between buck-passing and hypervigilance decision making styles of preschool teachers belonging to average and good income groups. On the other hand, a significant difference has been found in favor of the teachers from high income group in terms of both buck-passing and hypervigilance decision making styles.

In the analyses carried out according to socio-economic levels, the preoccupied attachment points of the individuals at a low socio-economic level have been found to be higher than those of the individuals at an average or high socio-economic level (Karaşar, 2014). A similar finding is seen in the studies of Yılmaz (2007) and Saymaz (2003). This result may stem from the fact that the individuals without sufficient economic opportunities value themselves negatively.

In their research, where they analyzed the self-esteem levels and decision making styles of teachers from different branches, Temel et al. (2015), found that sex, age, marital status, education level and parents' education level do not differ according to demographic features.

In addition, different studies (Taşdelen, 2002; Köse, 2002; Deniz, 2002; Avşaroğlu, 2007; Çetin, 2009) have concluded that self-esteem in decision making and decision making styles do not have a significant difference according to age and sex variables.

As to the effect of father's education level on the decision making style, teachers whose fathers are primary school or university graduates have higher levels of decision making and self-esteem than the ones with fathers at other education levels.

In the comparison made according to father's education level, no significant difference has been observed related to attachment styles. It can be said that this result may stem from the fact that mothers have a more important role in attachment theory (Karaşar, 2014). In the comparison made according to mother's education level, no significant difference has been observed related to attachment styles, either. The interpretation of this result could be that the education level of the mother is not effective in the emotional bond established especially with the mother. Because motherhood is instinctive, mother's education level might not have caused a difference (Karaşar, 2014).

As for the buck-passing decision making style, the points of the individuals with authoritarian and protective parents are higher than the individuals with democratic and tolerant parents. About hypervigilance decision making, the points of the individuals with protective parents are higher than the individuals whose parents are democratic and tolerant.

The individuals from average income group have higher points of secure relationship. The point of high income group is higher than good income group. However, no significant difference has been found between individuals from average income group and high income group.

The preoccupied relationship points of preschool teachers exposed to protective and authoritarian behaviours are higher than the points of those exposed to democratic behaviours. The dismissing relationship points of preschool teachers treated indifferently by their parents are higher than those of all these groups.

As for the relation between decision making styles and attachment, there is no significant relation between vigilance decision making style and attachment styles. There is a weakly and very weakly significant relation between buck-passing, procrastination, hypervigilance decision making styles and fearful, preoccupied, dismissing attachment styles.

In the research conducted with teacher candidates by Erözkan (2011), secure attachment was observed to have positively significant relations with rational decision making and dependent decision making strategies. However, secure attachment has negative relations with impulsive decision making and indecisiveness strategies.

According to Deniz's (2011) study, there is no significant relation between fearful attachment style and vigilance decision making style, whereas vigilance decision making style has a positively significant relation with dismissing attachment and secure attachment styles, and has a negatively significant relation with preoccupied attachment style.

No significant relation between secure attachment style and decision making styles has been found in this research. In other words, there is no relation between mother-child attachment and the person who searches for the necessary 
information and evaluates alternatives before making a decision.

In preschool classroom settings, the time period when there is one-to-one interaction between the teacher and the child is becoming an accepted reality (Pianta, 2006; Hamre \& Pianta, 2007). What is striking about these interactions is the emotional support that the teacher gives and the classroom adjustment (Downer, Sabol \& Hamre, 2010). Classroom management must include classroom adjustment which facilitates children's learning activites, enables their security and provides a sustainable setting (Carter \& Doyle, 2006).

The emotional support given to the child includes warmly and sensitively supporting his autonomy and valuing his ideas. These behaviours, in return, strengthens the child's relationship with the teacher and increases his motivation towards learning (Bowlby, 1969; Connell \& Welborn, 1991). The adjustments the teacher makes in the classroom include children's behaviours, activities, teacher's protective measures, instructions to maintain children's interest in learning and behaviours to minimize the number of possible problems in the classroom (Emmer \& Stough, 2001; Pintrich, 2000).

It can be said that recently there has been an increasing number of studies making use of attachment theory in explaning interpersonal relationships in organizations. In their research, where they analyze the factors affecting self-sufficiency in academic and work life, Wright, Perrone-McGovern, Boo ve Vannatter (2014) state that individuals with secure attachment style perceive more social support and fewer career obstacles as well as having high competencies in both academic and work life. In this study, individuals with secure attachment can be said to be more successful in work life.

Supportive behaviours with emotional content positively affect children's interest and participation in school settings. The positive attitude of the teacher and a child-oriented environment have proven to be related to children's showing desired behaviours in the classroom (Pianta, La Paro, Payne, Cox, \& Bradley, 2002).

In order to be effective, teachers must be in contact with children and treat them in a warm, respectful and trustworthy manner. It may be easier for teachers to establish attachment relationships in preschool or primary school classrooms, where they spend more time with students compared to secondary schools, and they may focus on a broader range of needs (Bergin \& Bergin, 2009).

\section{Suggestions}

As a result of the findings of the research, the following suggestions can be made;

1) Teacher candidates in preschool education must be aware of their own attachment style, observe themselves in practice and internship, be made to discover the background of their attitudes and behaviours in their relationships with children.

2) Because mostly child-mother attachment is searched in current kindergartens, it is important to conduct more research on teachers' own attachment styles and child-teacher attachments (different attachment figures).

3) In addition to attachment and decision making styles, classroom management skills must be integrated for further research on the relationship among these three.

4) In terms of attachment styles, analyzing with various testing instruments (observation reports, scales) the communication that preschool teachers establish with children in the classroom and getting feedback will contribute to children's socio-emotional development, adaptation skills and academic skills.

5) Through raising awareness of families, it can be made possible to improve parents-child relationship, which will result in families positively contributing to the ongoing attachment processes. Especially fathers must be made to be more active in this process.

\section{References}

Akdağ, Z., \& Haser, Ç. (2016). Beginning early childhood education teachers' classroom management concerns. Teachers and Teaching, 22(6), 700-715. https://doi.org/10.1080/13540602.2016.1158959

Ata, S. (2014). The investigation of relationships between preschool teachers attachment classroom management profile and attachment, child rearing attitude of mother (Master thesis, Hacettepe University Graduate Education Institute, Primary Education Department, Ankara).

Avsaroglu, S. (2007). Analyzing of decisional self-esteem, decision-making, self-esteem and coping with stress styles of college students in terms of some variables (Unpublished doctoral Thesis). Selçuk University, Konya, Turkey.

Balkıs, M. (2007). The relationship between pre-service teachers' procrastination tendency and their decision making styles. Pamukkale University Journal of Social Science Institute, 21(1), 67-83. 
Bartholomew, K., \& Horowitz, L. M. (1991). Attachment styles among young adults: a test of a four category

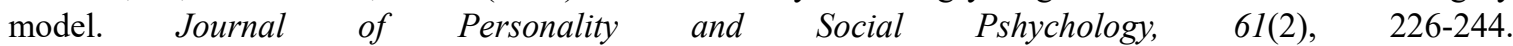
https://doi.org/10.1037/0022-3514.61.2.226

Batçıoğlu, G. (1994). Analysis of the decision making process (Master thesis, İnönü University Institute of Social Sciences, Department of Educational Sciences, Malatya).

Bergin, C., \& Bergin, D. (2009). Attachment in the classroom. Educational Psychological Review, 21(2), 141-170. https://doi.org/10.1007/s10648-009-9104-0

Bowlby, J. (1969). Attachment. Attachment and loss (Vol. 1. Loss). New York: Basic Books.

Bowlby, J. (1973). Attachment and loss: Separation, anxiety and anger. New York: Basic Books.

Bowlby, J. (2012). Attachment. İstanbul: Pinhan Publishing.

Büyüköztürk, Ş., Kılıç Çakmak, E., Akgün, Ö. E., Karadeniz, Ş., \& Demirel, F. (2016). Scientific Research Methods (22nd ed.). Ankara: Pegem Academy Publications.

Carter, K., \& Doyle, W. (2006). Classroom management in early childhood and elementary classrooms. In C. Evertson, \& C. Weinstein (Eds.), Handbook of classroom management: Research, practice, and contemporary issues (pp. 373-406). New York: Erlbaum.

Cetin M. C. (2009). In Terms of Some Variables the Comparatively Analysis of DecisionMaking Styles, Social Skill Levels, and Forms of Coping With Stress the Students of the Physical Education and Sports School (Unpublished Ph.D thesis, Gazi University, Ankara).

Collins, N. L., \& Read, S. J. (1990). Adult attachment, working models, and relationship quality in dating couples. Journal of Personality and Social Psychology, 58(4), 644-663. https://doi.org/10.1037/0022-3514.58.4.644

Connell, J. P., \& Wellborn, J. G. (1991). Competence, autonomy, and relatedness: A motivational analysis of self-system processes. In M. R. Gunnar, \& L. A. Sroufe (Eds.), The Minnesota symposia on child psychology, Vol. 23. Self processes and development (pp. 43-77). Lawrence Erlbaum Associates, Inc.

Çorapçı, A. (2015). Determination of classroom teachers' decision-making styles and job satisfaction levels (Master's thesis, Karamanoğlu Mehmetbey University Institute of Social Sciences, Department of Physical Education and Sports Education, Karaman).

Deniz, M. E. (2002). The study in a comparative manner of university students' decision-making strategies and TA-dominant status of me of the social skills levels and in terms of certain personal qualities (Unpublished doctoral thesis). Selcuk University, Konya, Turkey.

Deniz, M. E. (2004). Investigation of the relation between decision making self-esteem, decision making style and problem solving skills of university students. Eurasian Journal of Educational Research, 15, 23-35.

Deniz, M. E. (2011). An investigation of decision making styles and the five-factor personality traits with respect to attachment styles. Educational Sciences: Theory \& Practice, 11(1), 97-113.

Downer, J., Sabol, T. J., \& Hamre, B. (2010). Teacher-child interactions in the classroom: Toward a theory of within- and cross-domaik links to children's developmental outcomes. Early Education and Development, 21(5), 699-723. https://doi.org/10.1080/10409289.2010.497453

Ejimofor, F. O. (2007). Principals' transformational leadership skills and their teachers' job satisfaction in nigeria. Cleveland State University, Education and Human Services, ETD Archive, 86. Retrieved from https://engagedscholarship.csuohio.edu/etdarchive/86

Emmer, E. T., \& Stough, L. (2001). Classroom management: A critical part of educational psychology, with implications for teacher education. Educational Psychologist, 36(2), 103-112. https://doi.org/10.1207/S15326985EP3602_5

Erözkan, A. (2011). University students' attachment styles and decision strategies. Internation International Journal of Eurasia Social Sciences, 2(3), 60-74.

Griffin, D., \& Bartholomew, K. (1994). The metaphysics of measurement: The case of adult attachment. In K. Bartholomew, \& D. Perlman (Eds.), Attachment processes in adulthood: Advances in personal relationships (Vol. 5, pp. 17-52). London: Jessica Kingsley Publishers.

Hamilton, C. E., \& Howes, C. (1992). A comparison of young children's relationships with mothers and teachers. New Directions for Child and Adolescent Development, Autumn (Fall), 41-59. 
https://doi.org/10.1002/cd.23219925705

Hamre, B. K., \& Pianta, R. C. (2007). Learning opportunities in preschool and early elementary classrooms. In R. C. Pianta, M. J. Cox, \& K. L. Snow (Eds.), School readiness and the transition to kindergarten in the era of accountability (pp. 49-83). Paul H Brookes Publishing.

Hariri, H. (2011). Leadership styles, decision-making styles, and teacher job satisfaction: An Indonesian school context ( $\mathrm{PhD}$ thesis, James Cook University).

Hariri, H., Monypenny, R., \& Murray, P. (2016). Teacher-perceived principal leadership styles, decision-making styles and job satisfaction: how congruent are data from Indonesia with the Anglophile and Western $\begin{array}{lllll}\text { literature? School Leadership \& } & \text { Management, } & 36(1), & \text { 41-62. }\end{array}$ https://doi.org/10.1080/13632434.2016.1160210

Hazan, C., \& Shaver, P. (1987). Romantic love conceptualized as an attachment process. Journal of Personality and Social Psychology, 52(3), 511-524. https://doi.org/10.1037/0022-3514.52.3.511

Howes, C., \& Ritchie, S. (2002). A Matter of Trust: Connecting Teachers and Learners in the Early Childhood Classrooms. New York: Teachers College Press.

Howes, C., Matheson, C. C., \& Hamilton, C. E. (1994). Maternal teacher and child care history corrolates of children's relationship with peers. Child Development, 65, 264-274. https://doi.org/10.2307/1131380

Hunter, D. (1979). Teaching is decision making. Association for Supervision and Curriculum Development. Retrieved from http://www.ascd.org/ASCD/pdf/journals/ed_lead/el_197910_hunter.pdf

Izgar, H., \& Y1lmaz, E. (2007). The relationship between decision-making self-esteem and decision-making styles of school administrators working in PIO and YIBO. Journal of Social Sciences Instution, 17, 341-351.

Jones, V., \& Jones, L. (2004). Comprehensive classroom management: creating communities of support and solving problems (7th ed.). Boston, MA: Pearson Education.

Karaşar, B. (2014). The relationship between teacher candidates' attachment styles and social anxiety levels. Amasya University Journal of Education, 3(1), 27-49.

Kirgil, F. (2015). Examination of the decision-making and assertiveness levels of physical education teachers and other branch teachers in terms of some variability (Master thesis, Firat University, Institute of Health Sciences, Elâzı ğ).

Kounin, J. S. (1970). Discipline and group management in classrooms. Holt, Rinehart \& Winston.

Koutouzis, M., \& Malliara, K. (2017). Teachers' job satisfaction: The effect of principal's leadership and decision-making style. International Journal of Education, 9(4), 71-89. https://doi.org/10.5296/ije.v9i4.10272

Köse, A. (2002). Psychological counseling and guidance first grade students personal preferences and decision making strategies regarding gender and socioeconomic status (Unpublished master thesis). Hacettepe University, Ankara, Turkey.

Mann, L., Radford, M., Burnett, P., Ford, S., Bond, M., Leung, K., ... Yang, K. S. (1998). Cross-Cultural differences in Self-Reported Decision-Making Style and Confidence. International Journal of Psychology, 33, 325-335. https://doi.org/10.1080/002075998400213

Morris-Rothschild, B. K. (2003). Teachers' Use of Conflict Management Styles: The role of Attachment and Efficacy (Dissertation thesis). Retrieved from http://umi.prequest.com

Pianta, R. C. (2006). Teacher-child relationship: Early literacy. In D. K. Dickinson, \& S. B. Neuman (Eds.), Handbook of Early Literacy Research (Vol. 2, pp. 113-135). NY: Guilford Press.

Pianta, R. C., \& Steinberg, M. S. (1992). Teacher-child Relationships and the Process of Adjusting to School. In R.C. Pianta (Ed.) Beyond the Parent: The Role of Other Adults in Children's Lives: New Directions for Child Development (Vol. 57, pp. 61-80). San Francisco: C.A. Jossey-Bass. https://doi.org/10.1002/cd.23219925706

Pianta, R. C., La Paro, K. M., Payne, C., Cox, M. J., \& Bradley, R. (2002). The relation of kindergarten classroom environment to teacher, family, and school characteristics and child outcomes. The Elementary School Journal, 102(3), 225-238. https://doi.org/10.1086/499701

Pintrich, P. R. (2000). The role of goal orientation in self-regulated learning. In M. Boekaerts, P. R. Pintrich, \& 
M. Zeidner (Eds.), Handbook of self-regulation (pp. 451-502). Academic Press. https://doi.org/10.1016/B978-012109890-2/50043-3

Saymaz, İ. (2003). Examining the relationship between university students' interpersonal relationships and attachment styles (Master thesis, Istanbul University Institute of Social Sciences, Istanbul).

Scott, S. G., \& Bruce, R. A. (1995). Decision-making style: The development and assessment of a new measure. Educational and Psychological Measurement, 55(5), 818-831. https://doi.org/10.1177/0013164495055005017

Simpson, J. A., \& Rholes, W. S. (1994). Stress and secure base relationships in adulthood. In K. Bartholomew, \& D. Perlman (Eds.), Advances in personal relationships, Vol. 5. Attachment processes in adulthood (pp. 181-204). Jessica Kingsley Publishers.

Simpson, J. A., Rholes, W. S., \& Phillips, D. (1996). Conflict in close relationships: An attachment perspective. Journal of Personality and Social Psychology, 71(5), 899-914. https://doi.org/10.1037/0022-3514.71.5.899

Sümer, N., \& Güngör, D. (1999). Psychometric evaluation of adult attachment styles on a Turkish sample and a cross-cultural comparison. Turkish Journal of Psychology, 14(43), 71-106.

Taşdelen, A. (2001). Pre-service teachers' decision making styles according to some psycho-social variables. Pamukkale University Journal of Education Faculty, 10, 40-52.

Taşdelen, A. (2002). Decision making styles of student teachers in relation to different psychological characteristics (Unpublished doctoral thesis). Dokuz Eylul University, Izmir, Turkey.

Temel, V., Birol, S. Ş., Nas, K., Akpınar, S., \& Tekin, M. (2015). Self-esteem in decision making styles of teachers. Educational Research and Reviews, 10(6), 744-750. https://doi.org/10.5897.ERR2015.2085

Trinke, S. J., \& Bartholomew, K. (1997). Hierarchies of attachment relationships in young adulthood. Journal of Social and Personal Relationships, 14(5), 603-625. https://doi.org/10.1177/0265407597145002

Wright, S. L., Perrone-McGovern, K. M., Boo, J. N., \& Vannatter, A. (2014). The influence of attachment on perceptions of supports and barriers to academic and career self-efficacy: A mediational model. Journal of Counseling and Development, 92(1), 36-46. https://doi.org/10.1002/j.1556-6676.2014.00128.x

Yilmaz, B. (2007). The relationship between university students' interpersonal communication skills and attachment styles (Master thesis, Social Sciences Institute, Mugla University).

Yılmaz, E., \& Altınok, V. (2010). Predicting teacher candidates' emotional intelligence levels in decision-making self-esteem and decision-making styles. Gazi University Journal of Gazi Educational Faculty, 30(3), 685-705.

\section{Copyrights}

Copyright for this article is retained by the author(s), with first publication rights granted to the journal.

This is an open-access article distributed under the terms and conditions of the Creative Commons Attribution license (http://creativecommons.org/licenses/by/4.0/). 